\title{
On two rare species of Plio-Pleistocene marine molluscs of the Mediterranean Basin
}

\author{
M. Mauro Brunetti
}

Calle Navas 106, 14511 Navas del Selpillar (Spain); e-mail: mbrunetti45@gmail.com

\begin{abstract}
During the study of the Plio-Pleistocene malacofaunas of the Mediterranean Basin, the presence of Liamorpha elegans (de Folin, 1870) was ascertained. This species has never been previously reported in sediments of the lower-middle Pliocene of central Italy and was reported only once in sediments of the upper Pleistocene (Tyrrhenian sensu Auctores) of southern Italy. Furthermore, the bivalve Tugonia anatina (Gmelin, 1791) was found in the Tyrrhenian of southern Spain. This is the second record in the upper Mediterranean Pleistocene after more than a hundred years; the specimen was compared with others, both from the Zanclean of the Guadalquivir Basin (Spain) and the Zanclean of Tuscany (Italy). Both species are discussed and illustrated.
\end{abstract}

KEY WORDS Pliocene; Pleistocene; Pyramidellidae; Myidae

Received 12.05.2020; accepted 11.11.2020; published online 12.12.2020

\section{INTRODUCTION}

During research on the Plio-Pleistocene malacofaunas of the Mediterranean Basin, the presence of the species Liamorpha elegans (de Folin, 1870) was ascertained. This species was described in the past as belonging to the genus Miralda A. Adams, 1863. Its presence is confirmed in the upper Pleistocene of southern Italy, with new findings, and is also reported for the first time in the lower-middle Italian Pliocene. During the same research, specimens of the bivalve Tugonia anatina (Gmelin, 1791) were found in sediments of the Spanish upper Pleistocene, a species previously reported for this period, only once many years ago (Gignoux, 1913).

\section{MATERIAL AND METHODS}

The material examined, collected during surface research, comes from various Pliocene deposits, both in the Guadalquivir basin (Gonzales Delgado,
1985, 1988, 1989, 1993; Landau et al., 2011), and from the Zanclean/Piacenzian of central Tuscany (Brunetti \& Della Bella 2006, 2008), the Tyrrhenian of Sicily (Ruggieri \& Greco, 1965) and that of southern Spain (Torres et al., 2006). For the generic and suprageneric determinations we followed the WoRMS (2020).

ABBREVIATIONS AND ACRONYMS. $\mathrm{H}=$ maximum height of the shell, measured from the apex to the end of the siphon canal; $\mathrm{L}=$ maximum width of the valve; coll. = collection; ex = speci$\mathrm{men} / \mathrm{s} ; \mathrm{CMB}=\mathrm{M}$. Mauro Brunetti collection.

\section{MATERIAL AND METHODS}

\section{Systematics}

Classis GASTROPODA Cuvier, 1797

Superfamilia PYRAMIDELLOIDEA Gray, 1840

Familia PYRAMIDELLIDAE Gray, 1840 
Genus Liamorpha Pilsbry, 1898

Type species Lia decorata de Folin, 1873

Liamorpha elegans (de Folin, 1870) - Figs. 1, 2

Mathilda elegans de Folin, 1870: 212-213, tab. 26, fig. 11

Pyrgulina sculptatissima Dautzenberg, 1910: 67, tab. 3, figg. 15-16

Miralda elegans (de Folin, 1870) - Hoenselaar \& Moolenbeek, 1990: p. 65 figg. 1-5

Miralda elegans (de Folin, 1870) - Crovato \& Micali, 1990: p. 125, tab. 1, fig. 2

Chrysallida pulchra Jeffreys, 1874 - Gaglini, 1992: 138, fig 146 (nomen nudum)

Liamorpha elegans (de Folin, 1870) - Aartsen, Gittenberger \& Goud, 1998: p. 9-11

Miralda elegans (de Folin, 1870) - Cossignani \& Ardovini, 2011: p. 349 (figure not numbered)

Miralda elegans (de Folin, 1870) - Peñas, Rolan \& Swinnen, 2014: p. 128, fig. 7 D-E

Examined material. Italy, Siena, Poggibonsi, località Cipressino, 1 ex, lower-middle Pliocene. Italy, Messina, Capo Milazzo, 2 ex, "Tirreniano".

REMARKS. For the discussion of this taxon at a generic level, see Aartsen et al. (1998), with which we agree. The characteristic sculpture of the teleoconca (Fig. 1A) prevents confusing the species with any other, fossil and living. Despite this, Dauteznberg (1910) described it as a new Pyrgulina sculptatissima, while admitting the strong resemblance to de Folin's species: “Cette petite espèce est remarquable par sa sculpture très saillante, qui lui donne un aspect bien particulier. Il se pourrait qu'elle fût la même que celle qui a été décrite et figurée par le Marquis de Folin dans les Fonds de la Mer, I, $p$. 212, pi. XXVI, fig. 11, sous le nom de Mathilda elegans: la sculpture est, en effet, fort semblable, mais, par contre, il n'est pas fait mention, dans la description, du pli columellaire qui est bien visible sur nos échantillons et qui fixe la classification de ce Mollusque parmi les Odostomidés".

Even Gaglini (1992: 138), while describing Chrysallida pulchra Jeffreys, 1874, a name unusable in any case due to it being a nomen nudum, admitted: "Non si può fare a meno di notare la rassomiglianza di questa specie con Miralda elegans". However, Liamorpha elegans features a quite variable teleoconch sculpture as specified also by Peñas et al.
(2014: 128): "there are some differences between populations in relations to the number of spiral cords which are on the lower part of the last whorl and the number of the axial ribs on its upper part".

Until now, the fossil finds of Liamorpha elegans were limited to a single record for the Upper Pleistocene of southern Italy (Crovato \& Micali, 1990), a presence confirmed in this contribution by the discovery of two further specimens of the Tyrrhenian of Capo Milazzo (Messina) (Fig.1B). Liamorpha elegans is part of the typical warm fauna with Senegalese affinity described by various authors (Gignoux, 1913; Trevisan \& Di Napoli, 1938; Mirigliano, 1953; Segre, 1954; Malatesta, 1954; Ruggieri \& Buccheri, 1968; Settepassi, 1971; Ruggieri \& Melone, 1975; Vazzana, 2008, Brunetti M., 2018). The specimen of the lower-middle Tuscan Pliocene was found in a characteristic sediment in Petaloconchus sp. previously described by Brunetti M. \& Della Bella $(2006,2008)$. According to Peñas et al. (2014), the species ranges from Guinea Bissau to Angola, where it is frequently found, with bathyal distribution from the infralittoral to the circalittoral. So far there are only two reports for the Mediterranean Sea (Hoenselaar \& Moolenbeek, 1990, Formentera \& Gaglini, 1991: Sicily) and for Mauritania (van Aartsen et al., 1998; Cossignani \& Ardovini, 2011).

Classis BIVALVIA Linnaeus, 1758

Ordo MYIDA Stoliczka, 1870

Superfamilia MYOIDEA Lamarck, 1809

Familia MYIDAE Lamarck, 1809

Genus Tugonia Gray, 1842

Type species Mya anatina Gmelin, 1791

Tugonia anatina (Gmelin, 1791) - Figs. 3, 4

Mya anatina Gmelin, 1791: 3221

?Tugonia anatina (Gmelin, 1791) - Hörnes, 1870: 32, tab. 6, figg $6 a-b$

?Tugonia (s. s.) taltassei Chavan, 1950: 31, fig. 1.

?Tugonia (s. s.) sherborni Glibert \& van de Poel, 1966: 37

?Tugonia (s. s.) sherborni Glibert \& van de Poel, 1971: 5, tab. 2, fig. 6 .

Tugonia anatina (Gmelin, 1791) - Pantoli \& Raffi, 1981: 73, tab. 1, figg. 1-20.

?Tugonia (Tugonia) anatina (Gmelin, 1790) - Santos \& Mayoral, 207: 47, tab. 1, fig. 9. 


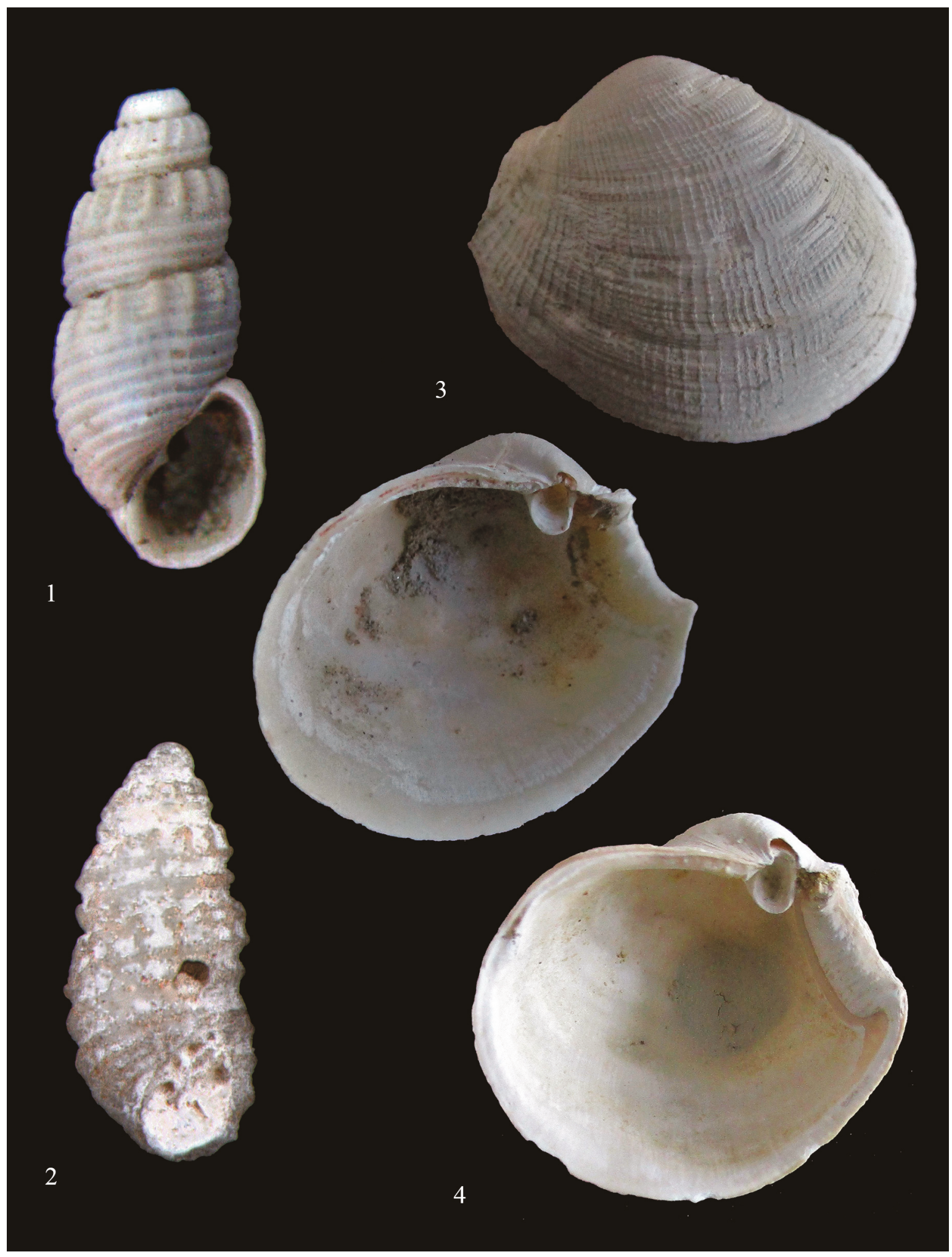

Figures 1, 2. Liamorpha elegans (de Folin, 1870). Fig. 1: Cipressino (Poggibonsi, Siena, Italy) lower-middle Pliocene, $\mathrm{H}=2.2 \mathrm{~mm}$ CMB X015. Fig. 2: Capo Milazzo (Messina, Italy), Tyrrhenian. H =1.6 mm CMB X015A. Figures 3, 4. Tugonia anatina (Gmelin, 1791). Fig. 3: Roqueta de Mar (Almeria, Spagna), Tyrrhenian, right valve L $=25.2 \mathrm{~mm}$ CMBS726. Fig. 4: Santa Catalina (Huelva, Spain), Zanclean, right valve L $=23$ mm CMBZ395. 
Tugonia anatina (Gmelin, 1791) - Chirli, 2015: 132, tab. 30, figg. 5-7.

EXAmined MATERIAL. Spain, Almeira, Roqueta de Mar, 1 ex, Tyrrhenian. Spain, Huelva, Santa Catalina, 20 ex, Zanclean. Italy, Siena, Poggibonsi, 5 ex.

REMARKS. This taxon too, due to the morphological characteristics of the valves, cannot be confused with other Plio-Pleistocene species. We were not able to examine current material, other than the material depicted in Pantoli \& Raffi (1981). Thus we hypothesized that living and Plio-Pleistocene populations belong to the same species. The specimen found in the Spanish Upper Pleistocene (Fig. 3 ) does not show significant differences with other Italian and Spanish examples of the lower Pliocene (Fig. 4), except for a greater sturdiness of the shell and a radial sculpture with less close ribs. Still to be clarified, in my opinion, is the relationship be- tween the Miocene species Tugonia taltassei Chavan, 1950 from the Tortonian of Morocco and Tugonia sherborni Glibert \& van de Poel, 1966 (Fig. 6 ), from the Portuguese upper Miocene, as well as the relationship with Tugonia anatina from Hörnes (1870) for the Austrian Miocene and from Santos \& Mayoral (2007) for the Portuguese Miocene. Whether all these species are valid or correspond to Tugonia ornata (Basterot, 1825) (Figs. 7, 8) is not the purpose of this paper. Only the examination and direct comparison of a greater number of specimens could definitively clarify the exact systematic position of the taxa treated. The specimen found comes from a layer of coarse sand mixed with reddish gravel (Fig. 5), one of the few Pleistocenic deposits Roqueta del Mar (Almeria, Spain) that survived the reckless urbanisation in the area. On the same level, Persistrombus latus Gmelin, 1791 (= Strombus bubonius Lamarck, 1822) and Conus ermineus Born, 1778, (= Conus testudinar-

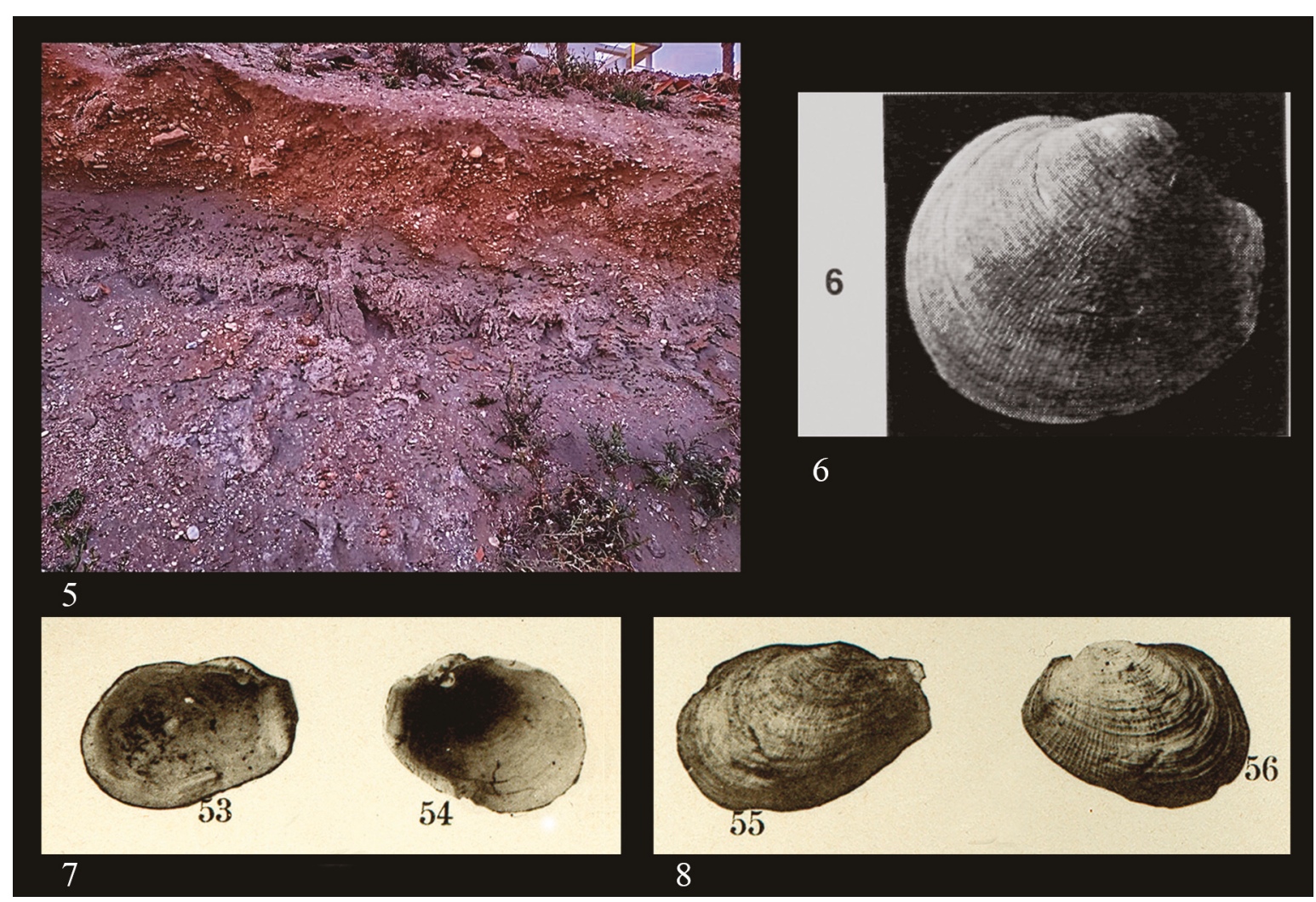

Figure 5. Geological level from which this specimen of Tugonia anatina comes. Figure 6. Tugonia (s. s.) sherborni Glibert \& van de Poel, 1966, holotype, Adiça (Portogalo), Tortonian, left valve L $=20 \mathrm{~mm}$, original figure rom Glibert \& van de Poel, 1971. Figures 7, 8. Tugonia ornata (Basterot, 1825) St. Avit (France) lower-middle Miocene, left valve L=20.2 mm, right valve $18.2 \mathrm{~mm}$. 
ius Hwass in Bruguière, 1792) have been found which allows us to date the valve of Tugonia anatina the Tyrrhenian period. The species had previously been reported only once by Gignoux (1913) in the Tyrrhenian of Monastir (Tunisia). This further report confirms that Tugonia anatina belongs to the well-known group of species with Senegalese affinity of the upper Pleistocene of the Mediterranean Basin.

\section{ACKNOWLEDGEMENTS}

We want to thank our friends: Juan José Escoriza Matéu (Roqueta del Mar, Almeria, Spain) for the photo of the Pleistocene level, Ermanno Quaggiotto (Longare, Vicenza, Italy) for the bibliographic help, Massimo Cresti (San Casciano VP, Florence, Italy) for the rereading some text and some valuable suggestions.

\section{REFERENCES}

Aartsen van J. J., Gittenberger E. \& Goud J., 1998. Pyramidellidae (Mollusca, Gastropoda, Heterobranchia) collected during the Dutch Cancap and Mauritania expeditions in the south-eastern part of the North Atlantic Ocean (part 1). Zoologische Mededelingen Leiden, 321: 3-57.

Cossignani T. \& Ardovini R., 2011. Malacologia Mediterranea. Ancona, L'Informatore Piceno, $536 \mathrm{pp}$.

Brunetti M.M. \& Della Bella G., 2006. Leufroyia ferrierii: una nuova specie per il Pliocene toscano (Gastropoda: Conidae). Bollettino Malacologico, 42: 118-120.

Brunetti M.M. \& Della Bella G., 2008. Macalia (?) kengii n. sp. un nuovo bivalve per il Pliocene toscano (Tellinidae, Macominae). Bollettino Malacologico, 44: 115-118.

Brunetti M.M., 2018. Two new records of fossil gastropods from the Italian upper Pleistocene. Biodiversity Journal, 9: 315-318.

Chavan A., 1950. Sur la présence du genre Tugonia dans le Miocène supérieur marocain. Cahiers géologiques de Thoiry, 3: 31-32.

Cossmann M. \& Peyrot A., 1907-1934. Conchologie néogenique de l'Aquitaine. Actes de la Société Linnéenne de Bordeaux, Bordeaux. Tome 63-86.

Crovato C. \& Micali P., 1990. Contributo alla conoscenza delle Chrysallidinae del Pliocene e del Pleistocene italiano. Lavori S.I.M., 24: 119-133.
Dautzenberg Ph., 1910. Mollusques marins. Mission Gruvel sur la Côte Occidentale d'Afrique (19091910). Annales de l'Institut Océanographique, Paris, Masson e C. Ed., 140 pp.

de Folin L., 1870. Quelques points de la côte occidentale d'Afrique, de Gorée, au Cap Sainte-Anne. In: de Folin L. \& Périer L. (Eds.), Les Fonds de la Mer 1(2), Savy, Paris, 316 pp.

Gaglini A., 1991. Terze spigolature... Monterosatiane. Argonauta, 7: 125-180.

Gignoux M., 1913. Les formations marines pliocénes et quaternaires de l'Italie du Sud et de la Sicilie, Thèses Faculté des Sciences de l'Université de Lyon, I A. Rey, Lyon, 393 pp.

Glibert M. \& van de Poel L., 1971. Mollusques cenozoiques nouveaux ou mal connus. Bullettin de l'Institut royal des Sciences naturelles de Belgique, 47: $1-17$.

Gmelin J.F., 1791. Vermes. In: Gmelin J.F. (Ed.), Caroli a Linnaei Systema Naturae per Regna Tria Naturae, Ed. 13. Tome 1(6). G.E. Beer, Lipsiae [Leipzig]. 3221 pp.

Gonzales Delgado J.A., 1985. Estudio sistématico de los Gastéropodos del Plioceno de Huelva (SW de España). 1. Archeogastropoda. Studia Geologica Salmanticensia, 20: 45-77.

Gonzales Delgado J.A., 1988. Estudio sistématico de los Gastéropodos del Plioceno de Huelva (SW de España). 3. Mesogastropoda (Scalacea-Tonnacea). Studia Geologica Salmanticensia, 25: 109-160.

Gonzales Delgado J.A., 1989. Estudio sistématico de los Gastéropodos del Plioceno de Huelva (SW de España). 3. Neogastropoda (Muricacea-Buccinacea). Studia Geologica Salmanticensia, 26: 269-315.

Gonzales Delgado J.A., 1993. Estudio sistématico de los Gastéropodos del Plioceno de Huelva (SW España). 5. Neogastropoda (Volutacea - Conacea). Studia Geologica Salmanticensia, 28: 7-69.

Hoenselaar H.J. \& Moolenbeek R.G., 1994. First records of Miralda elegans (De Folin, 1870) nov. comb. from the Mediterranean See (Gastropoda, Pyramidellidae). Bollettino Malacologico, 26(1-4): 65-66.

Hörnes M., 1856-1870. Die fossilen Mollusken des Tertiär-beckens von Wien. Abhandlungen der Kaiserlich-Königlichen Geologischen Reichsanstaldt, 4: $1-479$.

Landau B., Da Silva C.M. \& Mayoral E., 2011. The Lower Pliocene gastropods of the Huelva Sands Formation, Guadalquivir Basin, Southwestern Spain. Palaeofocus, 4: 1-90.

Malatesta A., 1954. Fossili delle spiagge Tirreniane. Bollettino del Servizio Geologico d'Italia, 76: 9-17.

Mirigliano G., 1953. La macrofauna del Tirreniano di Gallipoli (Lecce). Italian Journal of Zoology, 20: 115-122. 
Pantoli D. \& Raffi S., 1981. Presenza del genere Tugonia (Myidae, Bivalvia) nel Pliocene mediterraneo. Bollettino della Società Paleontologica Italiana, 20: 7380.

Peñas A., Rolan E. \& Swinnen F., 2014. The superfamilia Pyramidelloidea Gray, 1840 (Mollusca, Gstropoda, Heterobranchia) in West Africa, 11. Addenda 3. Iberus, 32: 105-206.

Ruggieri G. \& Greco A., 1965. Studi geologici e paleontologici su Capo Milazzo con particolare riguardo al Milazziano. Geologica Romana, 4: 41-88.

Ruggieri G. \& Buccheri G., 1968. Una Malacofauna tirreniana dell'isola di Ustica (Sicilia). Geologica Romana, 7: 27-58.

Ruggieri G. \& Melone G., 1975. La malacofauna del Tirreniano di Tommaso Natale (Palermo). Bollettino Società Paleontologica Italiana, 12: 217-222.

Santos A. \& Mayoral E., 2007. Paleoecología de la malacofauna de bivalvos del Mioceno superior de Cacela
(SE Portugal). Treballas de Museu Geologico de Barcelona, 15: 25-49.

Segre A.G., 1954. Il Tirreniano del golfo di Terranova Pausania (Olbia) e la sua fauna malacologica. Bollettino del Servizio Geologico d'Italia, 76: 43-84.

Settepassi F., 1971. Atlante malacologico I molluschi marini viventi nel Mediterraneo. Vol. 2, Inivag, $250 \mathrm{pp}$.

Torres T., Ortiz J.E., Puche O., de la Vega R. \& Arribas I., 2006. Biometría de Strombus bubonius Lamark 1791 del yacimiento de Cerro Largo (Roquetas de Mar, Almería). Geogaceta, 40: 167-170.

Trevisan L. \& Di Napoli E., 1938. Tirreniano, Siciliano e Calabriano nella Sicilia sudoccidentale. Estratto Giornale di Scienze Naturali ed Economiche, 39: 1-39.

Vazzana A., 2008. Ranilia constricta (Milne Edwards, 1880) nel Tirreniano di Trumbacà vicino Reggio Calabria. Il Naturalista siciliano, 32: 381-388.

WoRMS, 2020. http://www.marinespecies.org/index.php del $17 / 5 / 2020$ 